\title{
Formation of socially oriented projects using the financial and investment mechanism in the field of environmental management
}

\author{
Ekaterina Georgievna Shein", Andrey Alexandrovich Payusov, and Alexander Vasilyevich \\ Kurdyumov
}

Ural State Economic University, 8 Marta, 62, 620144 Yekaterinburg, Russia

\begin{abstract}
The research is devoted to the development of ideas for application of the financial and investment mechanism in the field of environmental management with the joint participation of the state and representatives of the business community. During the research, the authors used methods of structural and logical analysis and expert assessments. The research hypothesis is based on the idea that the implementation of socially oriented projects in the field of environmental management should be carried out using the financial and investment mechanism of public-private partnership. At the same time, the state will get not only an economic effect in the form of reducing the payback period of investment projects and a positive financial result, but also a social effect in the form of attracting business to environmental problems, supporting special tourist zones of the country and introducing ecotourism and a healthy lifestyle of the nation among preschool and school-age children. The authors analyzed scientific approaches to understanding the term "social entrepreneurship", the author's definition of social entrepreneurship and social investment is supplemented and proposed, five business processes are identified and classified in which a social enterprise is developed and financed. As practical recommendations for combining the ideas of social entrepreneurship in the field of ecotourism, justified by certain authors of business processes, and the use of a financing mechanism in the form of public-private partnership on the example of the already tested scheme for obtaining annual vouchers to children's country camps, the socially oriented investment project Academy "Go green hand" is proposed to support the domestic tourism industry and develop investments in the country's ecology.
\end{abstract}

\section{Introduction}

At the present stage of development of the Russian economy, the growing interest in the phenomenon of social entrepreneurship on the part of the state, the business community and science are not accidental. The desire to improve the financial stability of enterprises in various industries and spheres of activity and the overall economic growth of the country is

* Corresponding author: shekat@mail.ru 
impossible without the social orientation of state support measures and social orientation of business. The emergence of innovative ideas and technological solutions, the development of startups is increasingly associated with the specifics of social entrepreneurship, which is classified as a certain type of business process or business model, but without directly considering the enterprise, the economic entity and the laws of its activities and financing. It is through the development of social entrepreneurship that it is possible to introduce investment projects into the country's economy in such important sectors as ecology, domestic tourism, culture, and art, which undoubtedly requires a sufficient theoretical and methodological base for scientific research in this area.

\section{Literature Review / State-of-Arts / Research Background}

Social entrepreneurship is located on the border of interaction between business, with the inherent main goal of making a profit, and charity, with the inherent main goal of creating value, which contributes to solving important economic, social, environmental, cultural, and moral problems of any country as a whole and individual categories of citizens, as well as entrepreneurs $[6,12]$.

In Economics, references to social entrepreneurship appeared in the 80 s of the XX century in the scientific space, generalized theoretical material was gradually formed. For the first time, the phenomenon of social entrepreneurship was reflected in the works of such foreign scientists as G. Dees, R. Dart, S. Shein, S. Venkataraman, J.S. Mort, J. Weerawardena, A.M. Pedro, M. McLean, J. Mehr and I. Marti, who paid more attention to the conceptual foundations of the formation of the conceptual apparatus in this area, based on the classical theory of entrepreneurship, presented in the works of R. Cantillon, A. Smith, K. Marks, J. Schumpeter, who singled out actions under conditions of risk and uncertainty of income, innovative approach, impact on the relationship between the social structure of society, industrial progress and process of capital functioning as the main characteristics of entrepreneurial activity. Thus, at this stage of the development of economic science, the concept of "social entrepreneurship" did not have its own individual features but was only identified as a whole with entrepreneurial activity [8, 21, 26, 32].

In the Russian economic literature, issues in the field of social entrepreneurship began to be covered later, in the works of M. Batalina, L. Taradina, Yu. Blagov, Yu. Aray, G. Izotova, N. Zvereva, A. Mukhin, I. Manakhova, A. Barkova, K. Egorova, E. Esipova, A. Tatarkin, A. Maslov, D. Gafarova, N. Voskolovych, N. Kadol, O. Sheyanenko, T. Martynova, N. Pouncival, Z. Sabirova. These studies are mainly descriptive and review-oriented and do not have the necessary theoretical, methodological and empirical basis.

In the beginning of XXI century in the practice the integration of communities occurs in the field of social entrepreneurship, examples of which are the creation of the European research community EMES (EMES European Research Network), which brings together various centers, business schools, educational institutions from 11 European countries and community learning social enterprise (Social Enterprise Knowledge Network) at Harvard business school [7].

The public, commercial and non-commercial sectors play an important role in the socioeconomic development of various countries. If in the middle of the XX century the commercial sector prevails in the economy of countries, by the end of the XX century market failures - under-production of public goods, social problems increase strengthens the role of the non-profit sector $[1,4]$. Awareness of the importance of the non-profit sector of countries has led to the development of several state programs to support social entrepreneurship in the form of subsidies, grants, and the development of a public-private partnership mechanism $[19,23]$. Thus, social entrepreneurship is inextricably linked to the investment process. 
In July 2019, the concept of "social entrepreneurship "in Russia was enshrined at the legislative level in Federal law No. 209-FZ "On the development of small and medium-sized businesses in the Russian Federation".

The purpose of forming the process of social entrepreneurship and investment development is to create a constantly functioning adaptive mechanism for the joint solution of existing and new social problems of Russian society by the state and non-governmental organizations $[10,17]$. The leading role is played by society, which puts forward a range of social needs, and the state, which creates rules and opportunities for their identification and satisfaction, as well as state and non-state organizations that solve social problems and meet social needs, including social enterprises.

\section{Methodology}

All over the world, there is a search for possible mechanisms for attracting private investment to solve socio-economic problems, which is reflected in the development of new forms of investment and financial strategies that have entered scientific use as categories of "social investment", "socially oriented investment", "impact investment", "social entrepreneurship".

The term "social entrepreneurship" is most often used to describe a phenomenon, and the term "social entrepreneur" - to describe an individual. According to English-American research, "social entrepreneurship" and "social entrepreneur" are considered synonymous $[11,24,30,33]$. Based on the authors' analysis of terminology, three approaches to the definition of social entrepreneurship can be distinguished, presented in table 1 .

Table 1. Analysis of approaches to social entrepreneurship definition

\begin{tabular}{|l|l|l|l|}
\hline No. & $\begin{array}{l}\text { Classification of the } \\
\text { scientific approach }\end{array}$ & $\begin{array}{l}\text { Authors, year of } \\
\text { publication }\end{array}$ & $\begin{array}{l}\text { Definition of term "social } \\
\text { entrepreneurship" }\end{array}$ \\
\hline 1 & Catalyst for social change & $\begin{array}{l}\text { Roberts \& Wood } \\
(2005)\end{array}$ & $\begin{array}{l}\text { Search for opportunities to } \\
\text { transform social change }\end{array}$ \\
\hline 2 & $\begin{array}{l}\text { Innovative source of social } \\
\text { impact }\end{array}$ & Mair, Marti (2006) & $\begin{array}{l}\text { Innovative use of resources for } \\
\text { social change }\end{array}$ \\
\cline { 3 - 5 } & $\begin{array}{l}\text { Perrini \& Vurro } \\
(2006)\end{array}$ & $\begin{array}{l}\text { Dynamic process of social } \\
\text { innovation development to } \\
\text { create social value }\end{array}$ \\
\cline { 3 - 5 } & $\begin{array}{l}\text { Schwab Foundation } \\
(2005) \text { Innovative activities aimed at } \\
\text { providing benefits to society in } \\
\text { terms of vulnerable segments of } \\
\text { the population }\end{array}$ \\
\hline 3 & $\begin{array}{l}\text { Achieving a double effect } \\
\text { financial and social) }\end{array}$ & $\begin{array}{l}\text { Laspragata \& Cotten } \\
(2003)\end{array}$ & $\begin{array}{l}\text { Formation of an entrepreneurial } \\
\text { strategy to achieve the financial } \\
\text { stability of the enterprise in the } \\
\text { framework of the } \\
\text { implementation of the chosen } \\
\text { social idea }\end{array}$ \\
\cline { 3 - 4 } & Fuqua School (2005) & $\begin{array}{l}\text { Striving for financial income } \\
\text { and social impact }\end{array}$ \\
\hline
\end{tabular}

Sources: [11, 24, 30, 33].

In Federal law of the Russian Federation No. 209-FZ "On the development of small and medium-sized businesses", the concept of "social entrepreneurship" is interpreted as an entrepreneurial activity aimed at achieving socially useful goals, contributing to the solution of social problems of citizens and society and carried out in accordance with the conditions provided for by this Federal law. According to this definition, social entrepreneurship and 
small and medium-sized businesses are practically equated, and the specifics of financing such enterprises and the mechanism for investing in social projects are not considered. The concept of "social investment" is also not highlighted and is not considered.

According to the authors, social investment is not equated with social entrepreneurship. It is customary to define three main principles of social investment:

1. profitability;

2. making a positive impact on society and environment;

3. responsible attitude to evaluating project results - investors should monitor whether the project is achieving its social or environmental goals.

Social investment helps to measure the externalities of doing business [2, 13, 15, 22].

Based on the terminological analysis of the concepts of "social entrepreneurship" and "social investment", and the identification of their key features, the authors developed the following definitions.

Social entrepreneurship is an activity that has a specific life cycle for creating and implementing social values that meet social needs and solve social problems while obtaining a new socio-economic effect and a positive financial result.

Social investor is an entity (individual or enterprise) that has free resources (material, labor, money) and is able to invest in the creation of social values that meet social needs and solve social problems while obtaining a new socio-economic effect and a positive financial result in conditions of increased risk.

The spread of social entrepreneurship in many countries was uneven, due to traditions, norms, and customs in relation to socially significant issues $[14,31]$. Now the popularity of this business area is typical for Russia.

\section{Case studies / experiments / demonstrations / application functionality}

According to Rosstat data, 3.5 million people visited Russia's national parks and reserves in 2018. Over the past five years, since 2013, visits to nature reserves and other protected areas have increased by more than six times. However, there is still no ecotourism infrastructure in Russia.

The authors have developed a socially oriented investment project in the sphere of ecotourism Academy "Go green hand" at the hotel complex "Romantic", located in the village of Arkhyz in the Karachay-Cherkessia Republic, the implementation of which will allow a funding mechanism in the form of public-private partnership not only from a theoretical point of view to instill in the citizens of our country care for nature, but also from a practical point to show the uniqueness of Russian nature, its original form, to teach children the rules of the "safe tourism".

The trends of stable growth of visitors in this territory have remained: if in the 2015/2016 season the tourist flow in the village of Arkhyz increased by $25 \%$, and in the 2016/2017 season - by $30 \%$ relative to the previous period, in 2017/2018 - by $47 \%$, and in $2018 / 2019$ - by $52 \%$ relative to the previous period. According to the rating Agency TASS, more than $65 \%$ of the guests of the village of Arkhyz were tourists who have already visited the resort.

The creation of this Academy for preschool and school-age children allows to develop the Concept of the target program No. 872-r dated 05.05.2018 "Development of domestic and inbound tourism in the Russian Federation for 2019-2025", established by the Government of the Russian Federation and implement the Federal project "Wildlife of Russia: save and see", aimed at the development of ecological tourism in Russia and the safety of animals listed in the Red book. 
In this regard, the implementation of the investment project Academy "Go green hand" has a social orientation: it is aimed at increasing the life expectancy of the nation, promoting a healthy lifestyle, and therefore will be actively supported by the state authorities of the Russian Federation, as well as being a priority for the administration of the Caucasus region.

The implementation of the Academy "Go green hand" project involves a qualitative marketing analysis of the tourist services market, which was conducted by the authors of the study (table 2).

Table 2. Ecotourism market parameters in Russia

\begin{tabular}{|l|l|}
\hline \multicolumn{1}{|c|}{ Character } & \multicolumn{1}{c|}{ Characteristics of the market for business } \\
\hline 1. By type of consumers & B-2-C \\
\hline $\begin{array}{l}\text { 2. By physical properties of the } \\
\text { product }\end{array}$ & $\begin{array}{l}\text { Educational and health-improving ecological tourist } \\
\text { sessions of the Academy "GO GREEN HAND" }\end{array}$ \\
\hline 3. Level of consumer income & Low, medium, high \\
\hline 4. By demographic characteristics & Market by age (from 5 years to 18 years) \\
\hline 5. By geographical coverage & All-Russian (national) \\
\hline
\end{tabular}

Source: compiled by the authors

The "Go green hand" Academy offers four programs: "Winter green hand", "Spring green hand", "Summer green hand", and "Autumn green hand". Participation in each of these programs allows a child of preschool and school age to get an "ECO-certificate", which indicates their personal data (full name, age group, program number, an indicative scale that reflects the success of passing theoretical and practical ECO-tourist courses (green - 90$100 \%$, yellow $-75-90 \%$, orange $-55-75 \%$, red - less than 55\%). This "ECO-certificate" in Russia will provide an opportunity to improve theoretical and practical knowledge on the ecologization and safety of tourism.

In table 3, the authors present the planned number of participants in the "Go green hand" Academy per session.

Table 3. Planned number of participants in the "Go green hand" Academy per session

\begin{tabular}{|l|c|c|c|}
\hline \multicolumn{1}{|c|}{ Group } & Age subgroup & $\begin{array}{c}\text { Number of } \\
\text { participants, } \\
\text { max people }\end{array}$ & $\begin{array}{c}\text { Planned load of } \\
\text { participants at the initial } \\
\text { stage of project } \\
\text { development, 70\% }\end{array}$ \\
\hline "Amateur ECO-tourist" & $6-8$ years old & 12 & 9 \\
\cline { 2 - 4 } & $9-10$ years old & 20 & 14 \\
\hline "Devotee ECO-tourist" & $11-13$ years old & 40 & 28 \\
\hline $\begin{array}{l}\text { "Fan CO-tourist" (14-17 } \\
\text { years old). }\end{array}$ & $14-17$ years old & 22 & 16 \\
\hline \multicolumn{2}{|c|}{ Total: 94 people } & 67 people \\
\hline
\end{tabular}

Source: compiled by the authors

The price of the tour (table 4) in addition to accommodation will include: comfortable rest rooms, showers in each room, bath and bathroom accessories (bathrobe, slippers, shampoo, soap, washcloth). A healthy ecotourist breakfast is also included. The hotels have a conference room and a game room. On the territory there is a running track and all the necessary equipment for gaming events. It is planned to create three sessions in one season of the "Go green hand" Academy. 
Table 4. Cost of an ecotourism trip to the "Go green hand" Academy, in rubles

\begin{tabular}{|c|c|c|c|c|c|c|}
\hline & $\begin{array}{l}\text { Food/ } \\
\text { accommodation }\end{array}$ & Rehabilitation & Entertainment & $\begin{array}{l}\text { Broadening } \\
\text { of outlook }\end{array}$ & Logistics & Total: \\
\hline $\begin{array}{l}\text { WINTER } \\
\text { GREEN } \\
\text { HAND }\end{array}$ & \multirow[t]{4}{*}{17282} & \multirow[t]{4}{*}{5900} & 9600 & 3000 & 16000 & $\begin{array}{l}51 \\
782\end{array}$ \\
\hline $\begin{array}{l}\text { SPRING } \\
\text { GREEN } \\
\text { HAND }\end{array}$ & & & 10050 & 2500 & 14000 & $\begin{array}{l}49 \\
732\end{array}$ \\
\hline $\begin{array}{l}\text { SUMMER } \\
\text { GREEN } \\
\text { HAND }\end{array}$ & & & 9900 & 2500 & 16000 & $\begin{array}{l}51 \\
582\end{array}$ \\
\hline $\begin{array}{l}\text { AUTUMN } \\
\text { GREEN } \\
\text { HAND }\end{array}$ & & & 10300 & 3000 & 14000 & $\begin{array}{l}50 \\
482\end{array}$ \\
\hline
\end{tabular}

Source: compiled by the authors

According to the Law of the Russian Federation dated 15.05.1991 No. 1244-1 "On social protection of citizens exposed to radiation as a result of the disaster at the Chernobyl NPP", the Federal law dated 21.12.1996 No. 159-FZ "On additional guarantees on social support of children-orphans and children left without parental care", the Federal law dated 24.07.1998 No. 124-FZ "On basic guarantees of child rights in the Russian Federation", the Federal law dated 24.04.2008 No. 48-FZ "On guardianship and custody", the Federal law dated 27.07.2010 No. 210-FZ "On organization of rendering state and municipal services", the Order of the Ministry of Education and Science of Russia dated 13.07.2017 No. 656 "On approval of example provisions on the organisation of rest of children and their rehabilitation", the Laws of constituent entities of the Russian Federation "On the organisation of rehabilitation, work and leisure of children and adolescents" for each calendar year applicants are provided with the issuance of subsidized vouchers to health camps and sanatoriums.

In accordance with paragraph 3 of part 1 of article 7 of Federal law No. 210-FZ dated 27.07.2010 "On the organization of state and municipal services", the applicant is granted an annual subsidy when receiving vouchers for certain categories of citizens and special conditions (table 5). The authors propose to include "Go green hand" Academy vouchers in the list of other vouchers to federal and municipal health camps, implementing this through a public-private partnership mechanism.

Table 5. Deadlines for submitting documents for granting a preferential permit

\begin{tabular}{|l|l|}
\hline Types of recreation and recovery organizations & Application deadlines \\
\hline Health camps (all sessions) & From April 1 to April 10 \\
\hline Health resorts (all periods of rehabilitation) & From April 25 to May 12 \\
\hline Camps with day stay & From April 1 to April 20 \\
\hline
\end{tabular}

Source: compiled by the authors

When considering the application, the amount of compensation specified in the application for the average cost of the trip is considered. If the application specifies $100 \%$ compensation for the average cost of a voucher to health camps and sanatoriums, and there are no free places in these camps, the application will be considered for children, the average cost of a voucher to which is compensated in the amount of $80 \%$.

In case of a positive response to the provision of a subsidized voucher, the multifunctional center provides the applicant with a receipt for payment of a voucher to the camp / sanatorium. Within 5 days from the date of receipt of the voucher, the applicant must pay for the voucher and notify by e-mail. 
Children from large families, orphans, and children who have any achievements in a field, ranging from creative to scientific activities, are entitled to receive a preferential voucher in the amount of $100 \%$ and $80 \%$ of the cost paid at the expense of the state. The list of individual achievements and their points are determined based on the regulations of the region. A similar mechanism of benefits is proposed to be implemented when receiving vouchers to the Go green hand Academy (tables 6, 7).

Table 6. Program of state support for children in obtaining an eco-trip voucher to the "Go green hand" Academy

\begin{tabular}{|l|l|l|}
\hline 1 line & 2 line & 3 line \\
\hline Social support & Support for gifted children & $\begin{array}{l}\text { Without } \\
\text { subsidy }\end{array}$ \\
\hline Low-income families & $\begin{array}{l}\text { Winners of all-Russian and international } \\
\text { olympiads in humanities, physical and applied } \\
\text { sciences }\end{array}$ & $\begin{array}{l}\text { Full } \\
\text { payment for } \\
\text { the voucher, } \\
\text { all other } \\
\text { willing }\end{array}$ \\
\cline { 1 - 2 } Large families & Winners of school olympiads, & \\
\cline { 1 - 2 } Child-orphans & \multicolumn{1}{|c|}{$80 \%$} & \\
\cline { 1 - 2 } Children with disabilities & $\begin{array}{l}\text { Active participants in sports and scientific } \\
\text { activities, volunteers }\end{array}$ \\
\cline { 1 - 2 } Children who have 1 parent & \\
\hline
\end{tabular}

Source: compiled by the authors

Table 7. Distribution of expenses of the state and consumers to pay for vouchers of the "Go green hand" Academy under the public-private partnership mechanism in 2021, in thousands rub.

\begin{tabular}{|l|l|l|l|l|c|}
\hline & $\begin{array}{l}\text { WINTER } \\
\text { GREEN } \\
\end{array}$ & $\begin{array}{l}\text { SPRING } \\
\text { GREEN } \\
\text { HAND }\end{array}$ & $\begin{array}{l}\text { SUMMER } \\
\text { GREEN } \\
\text { HAND }\end{array}$ & $\begin{array}{l}\text { AUTUMN } \\
\text { GREEN } \\
\text { HAND }\end{array}$ & Total: \\
\hline \multicolumn{7}{|c|}{ State } \\
\hline $100 \%$ & - & 7182,0 & 7151,0 & 7332,0 & 21665,0 \\
\hline $80 \%$ & - & 5746,0 & 5721,0 & 5866,0 & 17332,0 \\
\hline \multicolumn{7}{|c|}{ Consumers } \\
\hline $100 \%$ & - & 7182,0 & 7151,0 & 7332,0 & 21665,0 \\
\hline \multicolumn{7}{|c|}{ Hotels "Romantic-1" and "Romantic-2" } \\
\hline Profit & - & 7182,0 & 7151,0 & 7332,0 & 21665,0 \\
\hline Total: & - & 7182,0 & 7151,0 & 7332,0 & 21665,0 \\
\hline
\end{tabular}

Source: compiled by the authors

Thus, the implementation of the "Go green hand" Academy project proposed by the authors will help to develop domestic ecotourism in Russia and promote the preservation of natural wealth among tourists and residents in the Zelenchuksky district of the KarachayCherkessia Republic.

\section{Conclusion}

Based on the study, the authors identified the features of social entrepreneurship development in various countries, analyzed the key trends in the development of five processes inherent in social entrepreneurship. The authors also determined that social entrepreneurship is the most important direction of innovative search for solutions to social problems in the country. 
Based on the terminological analysis, the author's definitions of "social entrepreneurship" and "social investment" are proposed. In addition, the key features of social entrepreneurship are identified.

As part of the research, a socially oriented investment project "Go green hand" Academy, aimed at preserving pristine nature, has been proposed as a development of ecotourism and environmental management in Russia, which can serve as a platform for holding scientific events, conferences, and seminars in the field of ecology. The main objective of the project is to promote a healthy lifestyle, increase the life expectancy of the population, and instill the skills of "safe" tourism. The authors provide a financial and economic justification for the feasibility of this project. Programs for children's sessions with a list of activities, courses, and medical services have been developed. Thus, the research hypothesis formulated by the authors is justified.

It is noted that further research on the development of ecotourism and environmental management ideas, in-depth study of organizational and managerial aspects of different types of social entrepreneurship models, and empirical analysis based on a wide sample of Russian regions will help to solve social problems and improve socio-economic indicators in the country.

\section{References}

1. Satu Aaltonen, International small business journal-researching entrepreneurship, 37(5), 551 (2019)

2. Taysir Asarkaya, Nurgul Keles, Nonprofit management \& leadership, 30(1), 155 (2019)

3. A.V. Barkov, Business law, 2, 28 (2012)

4. D. Celebi, I. Pirnar, E.D. Eris, Tourism, 68(1), 58 (2020)

5. Vijaya Sherry Chand, Journal of entrepreneurship, 29(1), 206 (2020)

6. Nicolae Cuta, Voluntas, 30(3), 614 (2019)

7. B. De la Hoz-Rosales, J. Camacho, I. Tamayo, Entrepreneurship and sustainability issues, 7(2), 782 (2019)

8. Marcelo Dionisio, Social enterprise journal, 15(1), 22 (2019)

9. Angela Dy, Adaku Jennifer Agwunobi, International journal of entrepreneurial behavior \& research, 25(8), 1727, (2019)

10. K.P. Egorova, E.Yu. Esipova, Bulletin of the International Institute of Management LINK, № 28, 130 (2012)

11. Philipp Erpf, Matthew J. Ripper, Melina Castignetti, Journal of social entrepreneurship, 10(3), 288 (2019)

12. G. Hamel, Best Business Books, 364 (2007)

13. V.P. Ivanitsky, S.A. Aleksandrov, Regional Economics, 13(3), 658 (2017)

14. Halima Jarrodi, Janice Byrne, Sylvain Bureau, Entrepreneurship and regional development, 31(7-8), 583 (2019)

15. Joohyung Ha, Conditional conservatism and labor investment efficiency (2018)

16. Merie Kannampuzha, Kai Hockerts, Social enterprise journal, 15(3), 290 (2019)

17. D.E. Klimanov, Russian Management Journal, 12(3), 107 (2014)

18. Kostopulos Dimitrios, Disentangling investor sentiment: Mood and household attitudes towards the economy (2018) Krasnoyarsk Science and Technology City Hall of the Russian Union of Scientific and Engineering Associations, 22057 (2019) 
19. Florian Lueckenbach, Carsten Baumgarth, Holger J. Schmidt, Cogent business \& management, 6(1), 1647820 (2019)

20. Mingming Feng, Deasing as a method of financing capital investments, 5, 3 (2019)

21. New social entrepreneurs: the success, challenge and lessons of non-profit enterprise creation, 417 (1996)

22. Sascha Bjarno Olinsson, Kalliopi Fouseki, Journal of cultural heritage management and sustainable development, 9(4), 486 (2019)

23. Na. Padilla-Zea, S. Aceto, D. Burgos, International journal of interactive multimedia and artificial intelligence, 5(7), 135 (2019)

24. S. Pathak, E. Muralidharan, Cross-cultural research, 54(2-3), 180, 1069397119865523 (2020)

25. A.A. Payusov, A.V. Kurdyumov, Management of economic systems, 11 (2019).

26. M. Porter, M. Kramer, Harvard Business Review, 73 (2007)

27. Filmby Aarhus, Alexandra Institute, High Tech Accelerator Innovation Center University Lodz Foundation, Report on business models, value chains and business development services in the audiovisual, creative industries: research report, 95 (2011)

28. Andrea Rey-Marti, Antonia Mohedano-Suanes, Virginia Simon-Moya, Sustainability, 11(4), 1175 (2019)

29. E.G. Sheina, M.Yu. Zavyalova, IOP Conference Series: search and environmental science

30. Social entrepreneurship education resource handbook, http://ashokau.org/

31. A.I. Tatarkin, A.V. Maslov, Bulletin of Ural Federal University. Series: Economics and Management, 3, 22 (2012)

32. Chitvan Trivedi, Journal of entrepreneurship, 28(1), 192 (2019)

33. M. Van Lunenburg, K. Geuijen, A. Meijer, Voluntas (2020) 